\title{
The Effect of Down Regulation of Protein Kinase C on the Inhibitory Modulation of Dorsal Root Ganglion Neuron $\mathrm{Ca}^{2+}$ Currents by Neuropeptide Y
}

\author{
Douglas A. Ewald, Heinrich J. G. Matthies, Teresa M. Perney, Mary W. Walker, and Richard J. Miller \\ Department of Pharmacological and Physiological Sciences, University of Chicago, Chicago, Illinois 60637
}

\begin{abstract}
Dorsal root ganglion (DRG) neurons cultured from neonatal rats contained high concentrations of protein kinase $C$ (PKC). Normally, the majority of the enzyme activity was found in the cytosol and considerably less was associated with the membrane fraction. Upon incubation with the phorbol ester phorbol dibutyrate (PDBu, $10^{-6} \mathrm{M}$ ) for $20 \mathrm{~min}$, PKC activity increased in the membrane-associated fraction and decreased in the cytoplasmic fraction. Longer incubations with phorbol ester also induced a decline in membrane-associated PKC activity. If incubations were continued for periods of over $10 \mathrm{hr}$, both membrane and cytosolic PKC activity declined essentially to zero. Down-regulation of PKC had no effect on the number or affinity of ${ }^{125}$-neuropeptide $Y$ (NPY) binding sites on DRG cells or on the absolute magnitude of the DRG $\mathrm{Ca}^{2+}$ current. However, the ability of NPY to inhibit the DRG $\mathrm{Ca}^{2+}$ current was greatly reduced. When sustained $\mathrm{Ca}^{2+}$ currents were evoked from depolarized holding potentials $(-40 \mathrm{mV})$, all concentrations of NPY $\left(10^{-10^{-1}}-10^{-7} \mathrm{M}\right)$ were less effective. In contrast, higher concentrations of NPY still blocked the transient portion of the DRG $\mathrm{Ca}^{2+}$ current evoked from hyperpolarized holding potentials. These results support the suggestion that PKC is involved in the inhibitory

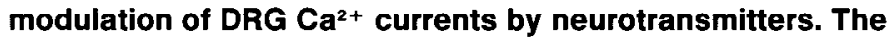
precise role of PKC may vary depending on the type of $\mathrm{Ca}^{2+}$ channel involved.
\end{abstract}

One way in which interneuronal communication can be regulated is by modulating the release of neurotransmitters. This may be achieved in a number of ways. For example, in some cases neuronal $\mathrm{K}^{+}$conductances may be modified (Kandel and Schwartz, 1982). However, one of the most direct mechanisms is by modulation of the voltage-dependent influx of $\mathrm{Ca}^{2+}$ into nerve terminals (Miller, 1987a, b). Indeed, the neurotransmitter-induced inhibition of neuronal $\mathrm{Ca}^{2+}$ currents has been observed in both vertebrates and invertebrates (Miller, 1987a, b). This inhibition has been associated with an inhibition of neurotransmitter release in several instances. This phenomenon has probably been most widely studied in dorsal root ganglion neurons (DRG cells) in vitro. In this case, the neurotransmitter-

\footnotetext{
Received July 8, 1987; revised Nov. 2, 1987; acceptcd Nov. 6, 1987.

Supported by PHS Grants DA-02121, DA- 02575 , and MH-40165, and by grants from Miles Pharmaceuticals and Marion Labs. H. J. G. Matthies, T. M. Perney, and M. W. Walker were supported by PHS Training Grant GM-07151.

Correspondence should be addressed to Richard J. Miller, Ph.D., Department of Pharmacological and Physiological Sciences, University of Chicago, 947 East 58th Street, Chicago, IL 60637.
}

Copyright (C) 1988 Society for Neuroscience $0270-6474 / 88 / 072447-05 \$ 02.00 / 0$ induced inhibition of the DRG Ca ${ }^{2+}$ current (Dunlap and Fischbach, 1981; Werz and MacDonald, 1984; Forscher and Oxford, 1985; Dolphin et al., 1986) is associated with a decrease in the evoked release of the undecapeptide substance P (Mudge et al., 1979; Holz et al., 1988; Walker et al., 1988).

Little is known, however, about the molecular mechanisms underlying the inhibition of $\mathrm{Ca}^{2+}$ currents in DRG cells or elsewhere. It has been observed that in DRG cells and in certain other cases synthetic derivatives of diacylglycerol (DAG) or phorbol esters can inhibit neuronal $\mathrm{Ca}^{2+}$ currents (Harris et al., 1985; Rane and Dunlap, 1986; Hammond et al., 1987). This has led to the suggestion that in DRG cells inhibition of $\mathrm{Ca}^{2+}$ currents may involve a protein kinase C-mediated pathway. A definitive proof of this hypothesis might involve the selective inhibition of neuronal PKC by a highly specific drug. Unfortunately, no such agent exists at this time. We have circumvented this problem by selectively depleting DRG cells of PKC by down-regulation (Matthies et al., 1987). We find that following this procedure the effects of the inhibitory neurotransmitter neuropeptide Y (NPY) (Walker et al., 1988) on DRG $\mathrm{Ca}^{2+}$ currents are greatly reduced.

\section{Materials and Methods}

Cell culture. DRG neurons were cultured from neonatal rats as previously described (Perney et al., 1986).

Protein kinase $C$ assays. DRG neurons were grown on $35 \mathrm{~mm}$ plates as described in Perney et al. (1986). Down-regulation and measurement of protein kinase C (PKC) activity was carried out exactly as described in Matthies et al. (1987). Briefly, the phorbol ester phorbol dibutyrate $\left(\mathrm{PDBu} ; 10^{-6} \mathrm{M}\right)$ was added to the culture medium for the indicated times and then washed out with fatty acid-free albumin prior to the experiment. Enzyme activity was determined by harvesting the cells and measuring the difference in phosphorylation of exogenous histone in the presence and absence of $\mathrm{Ca}^{21}$ (Palfrey and Waseem, 1985). The assay medium contained $50 \mathrm{~mm}$ Tris- $\mathrm{HCl}(\mathrm{pH} 7.4), 5 \mathrm{~mm} \mathrm{MgSO}_{4}, 1$ mM EGTA or $0.5 \mathrm{~mm} \mathrm{Ca}^{2+}, 50 \mu \mathrm{g} / \mathrm{ml}$ phosphatidylserine, $0.2 \mathrm{mg} / \mathrm{ml}$ histone $\mathrm{Hl}$, and $50 \mu \mathrm{M} \mathrm{AT} \mathrm{T}^{32} \mathrm{P}(100-500 \mathrm{mCi} / \mathrm{mmol})$.

Receptor binding assays. Binding assays were performed as in Walker et al. (1988).

Electrophysiology. DRG Ca ${ }^{2+}$ currents were measured using the wholecell voltage-clamp paradigm as described previously by Walker et al. (1988).

\section{Results}

Neonatal rat DRG cells contained high concentrations of PKC. Under normal conditions, about $90 \%$ of the enzyme activity was associated with the cytoplasmic fraction and only a minor portion with the cell membrane fraction. As has been observed with other cell types (Matthies et al., 1987), addition of the active phorbol ester, $\mathrm{PDBu}\left(10^{-6} \mathrm{M}\right)$ produced a rapid translo- 


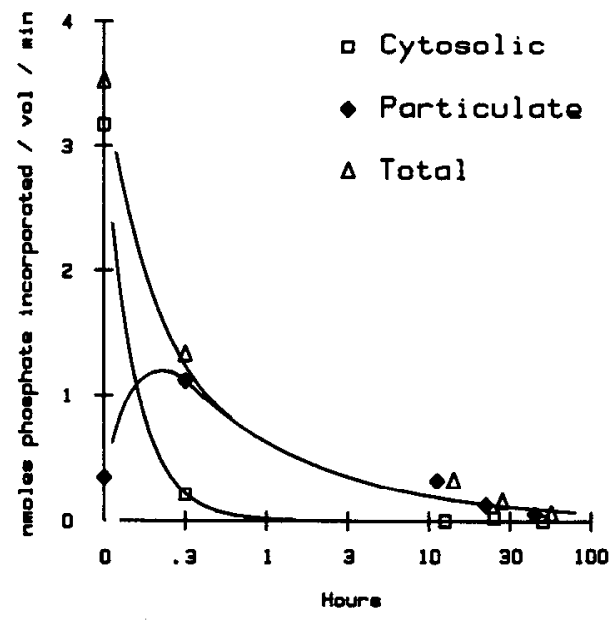

Figure 1. Time course of translocation and down-regulation of PKC in DRG neurons. After pretreatment with phorbol dibutyrate $(1 \mu \mathrm{M})$ for the times shown, cultured DRG neurons were homogenized and separated into cytosolic and particulate fractions by standard ultracentrifugation techniques. PKC activity was assessed as the difference in phosphorylation of exogenous histone in the presence and absence of $\mathrm{Ca}^{2+}$ (Palfrey and Wasecm, 1985). The time courses of total activity and cytosolic activity are fitted with single-exponential curves. The curve for particulate activity is the difference between the 2 exponential curves.

cation of enzyme activity (Fig. 1). Twenty minutes after adding PDBu $\left(10^{-6} \mathrm{M}\right)$, the PKC activity associated with the cell membrane fraction had increased considerably, whereas it had declined in the cytoplasm. We have previously shown that longterm treatment of cultured sympathetic neurons or $\mathrm{PCl} 2$ cells with phorbol esters leads to the down-regulation of PKC (Matthies et al., 1987). This phenomenon has also been observed in many other cell types (Ashendel, 1985). Similar effects were observed in DRG cells. Thus, on prolonged incubation with $\mathrm{PDBu}, \mathrm{PKC}$ activity began to decline in the membrane-associated fraction as well. The total cellular PKC activity declined exponentially over time. Following about $10 \mathrm{hr}$ of continuous treatment, PKC activity associated with both the cytosolic and membrane fractions had decreased to nearly background levels. Even longer incubations decreased all activity essentially to zero. It should be noted that following chronic phorbol ester treatment the cellular activity of $\mathrm{Ca}^{2+} /$ calmodulin-dependent kinase was virtually unaltered. This has been generally found to be the case in other cell types as well (Matthies et al., 1987). Chronic treatment of DRG cells with PDBu had no effect on the cellular complement of NPY receptors or on their affinity $\left(B_{\max }=260\right.$ $\mathrm{fmol} / \mathrm{mg}$ prior to and $275 \mathrm{fmol} / \mathrm{mg}$ following $20 \mathrm{hr}$ of PDBu treatment, $K_{D}=0.90 \mathrm{nM}$ prior to and $0.75 \mathrm{nM}$ following $20 \mathrm{hr}$ of $\mathrm{PDBu}$ treatment). Furthermore, if cells were treated for 16 to $48 \mathrm{hr}$ with $\mathrm{PDBu}$, the absolute magnitude of the $\mathrm{DRG} \mathrm{Ca}^{2+}$ current was also unaltered. [Average total $\mathrm{Ca}^{2+}$ current $\pm \mathrm{SD}$ was $1.10 \pm 0.48 \mathrm{nA}(n=15)$ on untreated and $0.93 \pm 0.37 \mathrm{nA}$ $(n=13)$ on treated cells.]

We examined the effects of NPY on $\mathrm{Ca}^{2+}$ currents in DRG cells following the down-regulation of PKC. As can be seen in Figures 2 and 3, NPY $\left(10^{-9}\right.$ and $\left.10^{-7} \mathrm{M}\right)$ normally greatly attenuated DRG Ca ${ }^{2+}$ currents. $\mathrm{Ca}^{2+}$ currents evoked from holding potentials of -80 or $-40 \mathrm{mV}$ were both inhibited. Figure 4 illustrates the relative effects of NPY on the transient and sustained portions of the DRG $\mathrm{Ca}^{2+}$ current. It can be seen that inhibition of both portions of the $\mathrm{Ca}^{2+}$ current was observed over similar concentration ranges. Following down-regulation of PKC, the ability of NPY to inhibit the sustained portion of the $\mathrm{Ca}^{2+}$ current was greatly reduced (Figs. 2,3). Figure 4 shows that this was true for all concentrations of NPY. In contrast, however, NPY was still able to substantially inhibit the transient portion of the DRG $\mathrm{Ca}^{2+}$ current evoked from hyperpolarized holding potentials. This was particularly so at higher concen-

\section{8 hr PdBu treatmont}
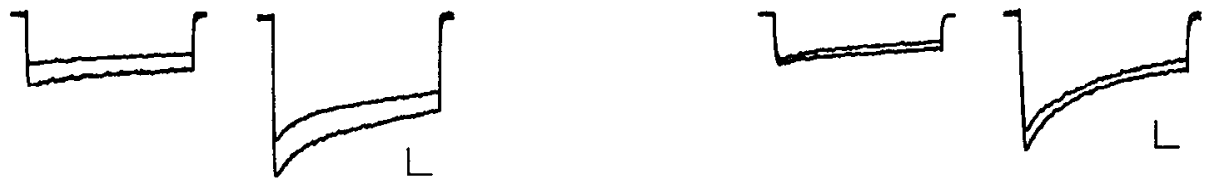

$-80 m V V_{h} \square_{\sigma_{0}} \frac{10^{-9} M \text { NPY }}{\sigma_{0}}$
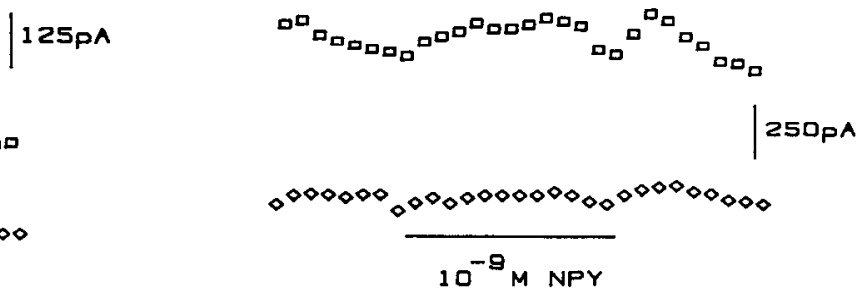

min.

10 M NPY

Figure 2. Effect of down-regulation of protein kinase $\mathrm{C}$ on the inhibition of $\mathrm{Ca}^{2+}$ currents by $10^{-9} \mathrm{M}$ NPY. DRG neurons were voltage-clamped in the whole-cell mode under ionic conditions optimal for the isolation of $\mathrm{Ca}^{2+}$ currents (see Materials and Methods). Voltage-clamp pulses (350 $\mathrm{msec}$ ) to $0 \mathrm{mV}$ were alternately given from holding potentials of $-80 \mathrm{mV}$ and $-40 \mathrm{mV}$ every $10 \mathrm{sec}$. The time course of effect of a $3 \mathrm{~min}$ exposure to $1 \mathrm{nM} \mathrm{NPY} \mathrm{is} \mathrm{plotted} \mathrm{for} \mathrm{the} \mathrm{sustained} \mathrm{current} \mathrm{(diamonds)} \mathrm{evoked} \mathrm{from} \mathrm{the}-40 \mathrm{mV}$ holding potential and for the transient plus sustained currents (squares) evoked from the $-80 \mathrm{mV}$ holding potential. The neuron shown at left was not treated with phorbol ester and the neuron downregulated for PKC for PDBu for $18 \mathrm{hr}$ is shown in the right. The traces compare currents just before exposure to NPY and $1 \mathrm{~min}$ after exposure to NPY. The inhibition of the transient and sustained currents caused by $10^{-9} \mathrm{M}$ NPY is completely blocked in the down-regulated neuron. Scale bars, 125 and $250 \mathrm{pA}$ and $50 \mathrm{msec}$. 

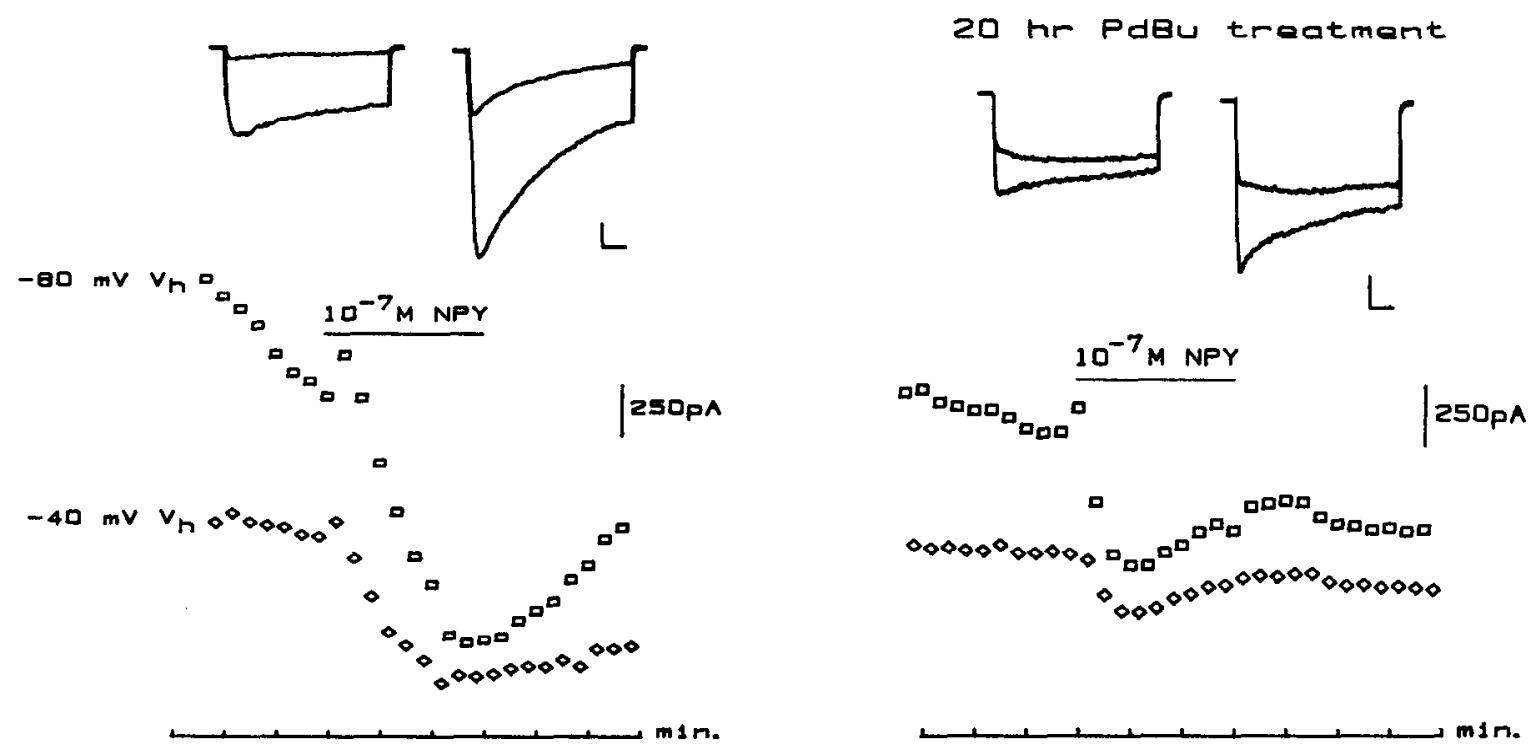

Figure 3. Effect of down-regulation of protein kinase $\mathrm{C}$ on the inhibition of $\mathrm{Ca}^{2+}$ currents by $10^{-7} \mathrm{M}$ NPY. The graphic format is identical to that in Figure 2. NPY greatly inhibited both transient and sustained currents with a time course of minutes. The neuron shown at right was downregulated for PKC by a $20 \mathrm{hr}$ preincubation with $1 \mu \mathrm{M}$ PDBu. Inhibition of the sustained current was substantially blocked, whereas inhibition of the transient current was not. Current traces at the top of both panels compare the sustained current (left) and the total current (right) after 2 min of exposure to NPY with the corresponding currents prior to exposure to NPY. Scale bars, $250 \mathrm{pA}$ and $50 \mathrm{msec}$.

trations $\left(10^{-7}\right.$ and $\left.10^{-8} \mathrm{M}\right)$. However, at lower concentrations $\left(10^{-9} \mathrm{M}\right)$, NPY was less effective in down-regulated cells.

\section{Discussion}

We have sought to examine the hypothesis that $\mathrm{PKC}$ is involved in mediating the inhibitory actions of neurotransmitters on DRG $\mathrm{Ca}^{2+}$ currents (Rane and Dunlap, 1986). This might be potentially achieved by using a specific inhibitor of the enzyme. However, no such compound is yet available. We have therefore circumvented the problem by using the down regulation of $\mathrm{PKC}$ following chronic phorbol ester treatment. Down-regulation of PKC is a commonly observed phenomenon that results from the degradation of the enzyme by proteases (Ballester and Rosen, 1985). Under these conditions the activity of other protein kinases, such as the $\mathrm{Ca}^{2+} /$ calmodulin-activated enzyme, is little altered (Ashendel, 1985; Matthies et al., 1987). The data obtained using this preparation indicate that $\mathrm{PKC}$ partially mediates the effects of NPY on the DRG $\mathrm{Ca}^{2+}$ current. There are several lines of evidence in addition to the data reported here that are also consistent with this proposal. We shall now discuss this evidence. We shall tentatively make the assumption that all inhibitory neurotransmitters (e.g., NPY, norepinephrine, GABA, adenosine, etc.) block DRG $\mathrm{Ca}^{2+}$ currents by using the same molecular transduction mechanism (Dunlap and Fishbach, 1981; Werz and MacDonald, 1984; Forscher and Oxford, 1985; Dolphin et al., 1986). Naturally, this may ultimately not prove to be the case. However, there is no evidence to the contrary at this time.

It is clear that receptors for inhibitory neurotransmitters on DRG cells are regulated by G-proteins. Thus, we have shown that the binding of NPY to its receptors on these cells can be modulated by the nonhydroylzable GTP analog, Gpp(NH)p (Walker et al., 1988). Furthermore, the effects of NPY, norepinephrine, and GABA can be inhibited by pertussis toxin (Holz et al., 1986; Walker et al., 1988), indicating the involvement of a $G$-protein of the $G_{0}$ or $G_{i}$ type. In addition, injection of stable
GTP analogs into DRG neurons enhances the ability of neurotransmitters to block DRG Ca ${ }^{2+}$ currents (Dolphin and Scott, 1987). Do G-proteins directly couple the receptors to $\mathrm{Ca}^{2+}$ channels as is the case for the coupling of muscarinic receptors in the heart to $\mathrm{K}^{+}$channels or is a diffusable second messenger involved? The answer to this question is not entirely clear. Forscher et al. (1986) reported that norepinephrine added outside a patch pipette did not inhibit $\mathrm{DRG} \mathrm{Ca}{ }^{2+}$ channel activity measured in on-cell patches within the pipette. This indicates direct receptor/channel coupling. However, it may be that the conditions used by these authors did not favor other observations. Indeed, we have observed inhibition of $\mathrm{Ca}^{2+}$ channel activity in this paradigm, provided that the experimental conditions are appropriate [i.e., smaller pipette apertures and longer agonist exposures (Ewald and Miller, 1987)].

Several authors have observed the inhibition of neuronal $\mathrm{Ca}^{2+}$ currents by phorbol esters in a variety of preparations, including DRG cells (Harris et al., 1985; Rane and Dunlap, 1986; Hammond et al., 1987; Werz and MacDonald, 1987). Thus, diacylglycerol (DAG) could represent a possible second messenger linking inhibitory receptors to DRG Ca ${ }^{2+}$ channels. This requires that inhibitory neurotransmitters stimulate the synthesis of DAG in DRG neurons. We have found that both NPY and norepinephrine powerfully stimulate DAG production by DRG cells (Perney and Miller, 1987). It should be noted that little inositol trisphosphate is produced, indicating that the source of this DAG may be a phospholipid other than phosphatidylinositol bisphosphate.

In down-regulated DRG cells the inhibitory effects of NPY are clearly reduced but are not completely absent. This result suggests some further complexity in the model described so far. Indeed, it is clear that the DRG $\mathrm{Ca}^{2+}$ current is a result of the activation of a variety of different $\mathrm{Ca}^{2+}$ channel types. In chick DRG cells, 3 types of $\mathrm{Ca}^{2+}$ channels designated $\mathrm{T}, \mathrm{L}$, and $\mathrm{N}$ have been described and their properties widely discussed (Nowycky et al., 1985; Miller, 1987a, b). The characteristics of the 

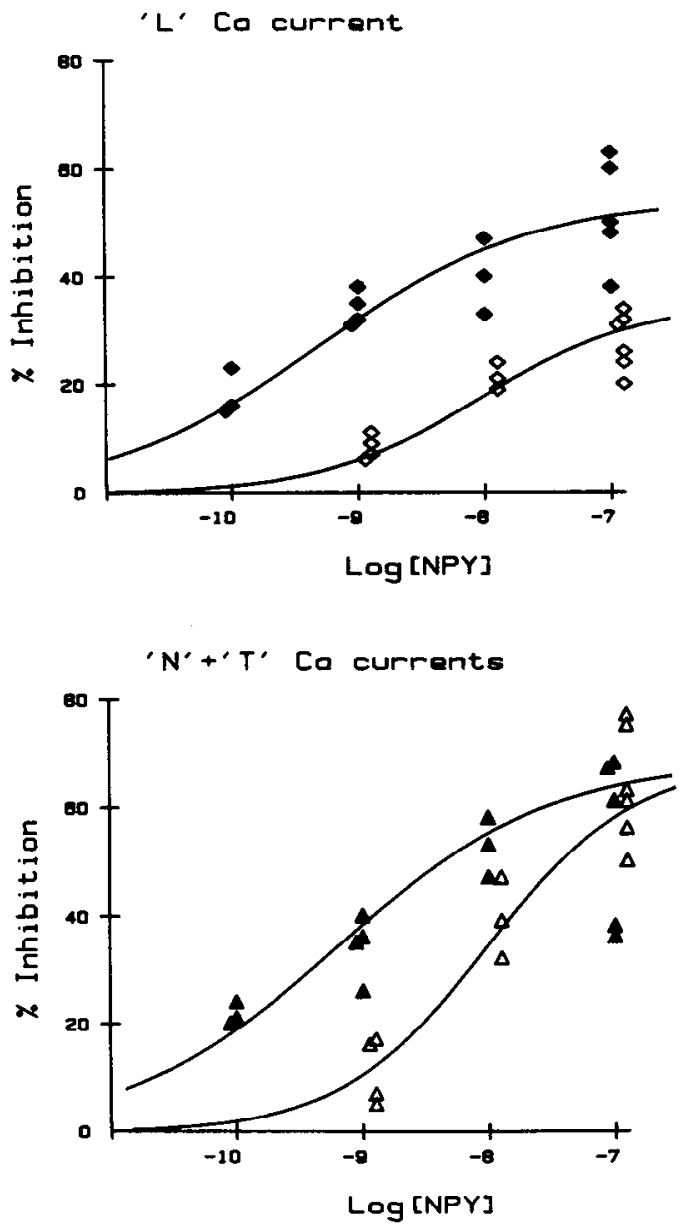

Figure 4. Dose-response curves for inhibition of sustained (L) and transient $(\mathrm{N}+\mathrm{T}) \mathrm{Ca}^{2+}$ currents in DRG cells by NPY. Control responses are indicated by filled symbols, and responses following down-regulation of PKC by preincubation with PDBu are indicated by open symbols. The total and sustained $\mathrm{Ca}^{2+}$ currents were plotted as a function of time. The time courses before exposure to NPY were extrapolated as a single exponential, and the percentage reduction at the end of the exposure was calculated relative to the extrapolations for the sustained and transient currents. (Transient current was defined as total current minus sustained current.) In control cells, half-maximal inhibition of both transient and sustained currents occurred at $10^{-9} \mathrm{M}$ NPY. Inhibition produced by $10^{-9} \mathrm{M}$ NPY was completely blocked in down-regulated neurons. At higher concentrations, inhibition was still apparent, but it was predominantly directed towards the transient current.

whole-cell $\mathrm{Ca}^{2+}$ currents measured in rat DRG neurons closely resemble those observed in chick DRG cells. Thus, it is quite likely that $\mathrm{T}, \mathrm{L}$, and $\mathrm{N}$ channels also exist in rat DRG cells. Nevertheless, it should be remembered that this may not be the case in that the kinetic and other properties of $\mathrm{T}, \mathrm{L}$, and $\mathrm{N}$ channels in rat DRG cells may differ in detail from those of their chick counterparts.

Rat DRG cell $\mathrm{Ca}^{2+}$ currents evoked from relatively depolarized holding potentials are rather sustained and probably represent primarily the activation of dihydropyridine-sensitive $\mathrm{L}$ channels. Neurotransmitter induced inhibition of these currents seems to be most affected by the removal of PKC. Inhibition of these currents seems to be greatly reduced in down-regulated cells. This seems reasonable, since the inhibitory effects of phorbol esters on chick DRG neuronal $\mathrm{Ca}^{2+}$ currents were observed using a paradigm that specifically examined L-type currents (Rane and Dunlap, 1986).
It is also clear that inhibitory neurotransmitters such as NPY block some of the transient part of the DRG Ca ${ }^{2+}$ current evoked from negative holding potentials. By analogy with chick DRG cells, these transient currents may be due to the activation of a combination of $\mathrm{N}$ - and T-type $\mathrm{Ca}^{2+}$ channels. It appears that removal of PKC has less effect on the ability of NPY to block this transient portion of the current. It may therefore be that a different molecular mechanism links NPY receptors to N/T channels. Specific neurotransmitter-induced inhibition of the "transient" portion of neuronal $\mathrm{Ca}^{2+}$ currents has been observed in a number of other systems (Gross and MacDonald, 1987; Heschler et al., 1987; Madison et al., 1987; Sturek et al., 1987; Wanke et al., 1987). In some cases the involvement of a pertussis toxin-sensitive G-protein has also been demonstrated (Holz et al., 1986; Heschler et al., 1987). Importantly, in down-regulated cells the residual ability of NPY to block transient $\mathrm{Ca}^{2+}$ currents occurs at higher concentrations than its presumed PKC-mediated effects (Fig. 4). The reported inhibitory effects of NPY on transmitter release from sympathetic or hippocampal neurons similarly occur at somewhat elevated concentrations (Wahlestedt et al., 1985; Colmers et al., 1987). Consistent with these observations is the notion that, in many neurons other than DRG cells, neurotransmitter release has been shown to be predominantly controlled by N-type $\mathrm{Ca}^{2+}$ channels (Perney et al., 1986; Hirning et al., 1987; Miller, 1987a, b). However, a totally consistent picture of the way in which neurotransmitter receptors are linked to the transient portion of the $\mathrm{Ca}^{2+}$ current is not apparent from our data. At low concentrations of NPY, for example, removal of PKC does decrease inhibition of the transient current. Thus, a complete description of the role of PKC in the modulation of presumed $\mathrm{T}, \mathrm{L}$, and $\mathrm{N}$ channels awaits study of this phenomenon at the single-channel level. Nevertheless, our data are clearly consistent with a role for PKC in the neurotransmitter-induced inhibition of at least a portion of the rat DRG $\mathrm{Ca}^{2+}$ current.

\section{References}

Ashendel, C. L. (1985) The phorbol ester receptor: A phospholipid regulated protein kinase. Biochem. Biophys. Acta 822: 219-242.

Ballester, R., and O. M. Rosen (1985) Fate of immunoprecipitatable protein kinase $\mathrm{C}$ in $\mathrm{GH}_{3}$ cells treated with phorbol-12-myristate-13acetate. J. Biol. Chem. 260: 15196-15199.

Colmers, W. F., K. Lukowiak, and Q. J. Pittman (1987) Presynaptic action of neuropeptide $\mathrm{Y}$ in the area CAl of the rat hipppocampal slice. J. Physiol. (Lond.) 383: 285-299.

Dolphin, A. C., and R. H. Scott (1987) Calcium channel currents and their inhibition by (-)-baclofen in rat sensory neurones: Modulation by guanine nucleotides. J. Physiol. (Lond.) 386: 1-17.

Dolphin, A. C., S. R. Forda, and R. H. Scott (1986) Calcium dependent currents in cultured dorsal root ganglion neurons are inhibited by an adenosine analogue. J. Physiol. (Lond). 373: 47-61.

Dunlap, K., and G. D. Fischbach (1981) Neurotransmitters decrease the calcium conductance activated by depolarization of chick sensory neurones. J. Physiol. (Lond.) 317: 519-535.

Ewald, D. A., and R. J. Miller (1987) Norepinephrine (NE) decreases the activity of $\mathrm{Ca}^{2+}$ channels and increases the activity of a $\mathrm{K}^{+}$-channel in cutured rat dorsal root ganglion (DRG) neurons. Biophys. J. 51: 4299.

Forscher, P., and G. S. Oxford (1985) Modulation of calcium channels by norepinephrine in internally dialyzed avian sensory neurons. $J$. Gen. Physiol. 85: 743-763.

Forscher, P., G. S. Oxford, and D. Schultz (1986) Noradrenaline modulates calcium channels in avian dorsal root ganglia cells through tight receptor channel coupling. J. Physiol. (Lond.) 379: 131-144.

Gross, R. A., and R. L. MacDonald (1987) Dynorphin A selectivity reduces a fast transient $(\mathrm{N})$ calcium current of mouse dorsal root ganglia neurons in cell culture (submitted). 
Hammond, C., D. Paupardin-Tritsch, A. C. Nairn, P. Greengard, and H. M. Gerschenfeld (1987) Cholecystokinin induces a decrease in $\mathrm{Ca}^{2+}$ current in snail neurons that appears to be mediated by protein kinase C. Nature 325: 809-811.

Harris, K. M., S. Kongsamut, and R. J. Miller (1985) Protein kinase $\mathrm{C}$ mediated regulation of calcium channels in $\mathrm{PC} 12$ pheochromocytoma cells. Biochem. Biophys. Res. Commun. 134: 1298-1305.

Heschler, J., W. Rosenthal, W. Trautwein, and G. Schultz (1987) The GTP binding protein $\mathrm{G}_{0}$ regulates neuronal calcium channels. Nature 325: 445-447.

Hirning, L. D., A. P. Fox, E. W. McCleskey, B. R. Olivera, S. A. Thayer, R. J. Miller, and R. W. Tsien (1987) Dominant role of N-type calcium channels in $\mathrm{K}^{+}$-evoked release of norepinephrine from rat sympathetic neurons. Science 239: 57-61.

Holz, G. G., S. G. Rane, and K. Dunlap (1986) GTP binding proteins mediate transmitter inhibition of voltage dependent calcium channels. Nature 319: 670-672.

Holz, G. G., R. M. Kream, and K. Dunlap (1988) Norepinephrine and $\gamma$-aminobutyric acid inhibit electrically evoked release of substance P from dorsal root ganglion neurons. J. Neurosci. 8: 463-471.

Kandel, E. R., and J. H. Schwartz (1982) Molecular biology of learning: Modulation of neurotransmitter release. Science 261: 6637-6639.

Madison, D. V., A. P. Fox, and R. W. Tsien (1987) Adenosine reduces an inactivating component of calcium currents in hippocampal $\mathrm{CA}_{3}$ neurons. Biophys. J. 51: 309.

Matthies, H. J. G., H. C. Palfrey, L. D. Hirning, and R. J. Miller (1987) Down regulation of protein kinase $\mathrm{C}$ in neuronal cells: Effects on neurotransmitter release. J. Neurosci. 7: 1198-1207.

Miller, R. J. (1987a) Multiple calcium channels and neuronal function. Science 238: 46-52.

Miller, R. J. (1987b) Calcium channels in neurones. In Structure and Physiology of the Slow Inward Calcium Channel, D. J. Triggle and J. C. Venter, eds., Plenum, New York 7: 161-246.

Mudge, A. W., S. E. Leeman, and G. D. Fischbach (1979) Enkephalin inhibits release of substance $\mathbf{P}$ from sensory neurons in culture and decreases action potential duration. Proc. Natl. Acad. Sci. USA 76: $527-532$.
Nowycky, M. L., A. P. Fox, and R. W. Tsien (1985) Three types of neuronal calcium channels with different calcium agonist sensitivity. Nature 316: 440-443.

Palfrey, H. C., and A. Waseem (1985) Protein kinase C in the human erythrocyte. J. Biol. Chem. 260: 16021-16029.

Perney, T. M., and R. J. Miller (1987) Neurotransmitter regulation of lipid metabolism in cultured rat sensory neurons. Soc. Neurosci. Abstr. 13: 1135 .

Perney, T. M., L. D. Hirning, S. E. Leeman, and R. J. Miller (1986) Multiple calcium channels mediate transmitter release from peripheral neurons. Proc. Natl. Acad. Sci. USA 83: 184-188.

Rane, S. G., and K. Dunlap (1986) Kinase C activator 1,2-oleylacetylglycerol attenuates voltage dependent calcium current in sensory neurons. Proc. Natl. Acad. USA 83: 184-188.

Sturek, M., L. D. Hirning, and R. J. Miller (1987) Opioid and adrenergic modulation of calcium currents in neurons from the rat myenteric plexus. Soc. Neurosci. Abstr. 13: 105.

Wahlestedt, C., N. Yamaihara, and R. Hakanson (1985) Evidence for different pre- and postjunctional receptors for neuropeptide $Y$ and related peptides. Reg. Peptides 13: 317-328.

Walker, M. W., D. A. Ewald, T. M. Perney, and R. J. Miller (1988) Neuropeptide $\mathrm{Y}$ modulates neurotransmitter release and $\mathrm{Ca}^{2+}$ currents in rat sensory neurons. J. Neurosci. $8: 2438-2446$.

Wanke, E., A. Ferroni, A. Malgaroli, A. Ambrosini, T. Pozzan, and J. Meldolesi (1987) A novel type of inhibition of voltage gated $\mathrm{Ca}^{2+}$ channels via muscarinic receptors in mammalian sympathetic neurons. Proc. Natl. Acad. Sci. USA 84: 4313-4317.

Werz, M. A., and R. L. MacDonald (1984) Dynorphin reduces calcium dependent action potential duration by decreasing voltage dependent calcium conductance. Neurosci. Lett. 46: 185-190.

Werz, M. A., and R. L. MacDonald (1987) Phorbol esters: Voltage dependent effects on calcium dependent action potentials of mouse central and peripheral neurons in cell culture. J. Neurosci. 7: 16391647. 